First publ. in: Journal of the American Chemical Society 128 (2006), 14, pp. 4572-4573 DOI: 10.1021/ja058262u

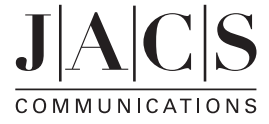

Published on Web 03/18/2006

\title{
The Genetic Incorporation of a Distance Probe into Proteins in Escherichia coli
}

\author{
Meng-Lin Tsao, Daniel Summerer, Youngha Ryu, and Peter G. Schultz* \\ Department of Chemistry and the Skaggs Institute for Chemical Biology, The Scripps Research Institute, \\ 10550 North Torrey Pines Road, La Jolla, California 92037
}

Received December 16, 2005; E-mail: schultz@scripps.edu

The unnatural amino acid $p$-nitrophenylalanine $\left(\mathrm{pNO}_{2}-\mathrm{Phe}\right)$ is a useful biochemical probe of protein structure and activity. ${ }^{1-4}$ When introduced into proteins either chemically or by in vitro biosynthesis, ${ }^{3-6}$ the $\mathrm{pNO}_{2}$-Phe group can quench the intrinsic fluorescence of nearby tryptophan (Trp) residues. The ability to genetically encode this amino acid in vivo would greatly facilitate the generation of $\mathrm{pNO}_{2}$-Phe mutants for both biochemical and cellular studies of protein structure and function. Previously, it was shown that unnatural amino acids can be site-specifically introduced into proteins in bacteria and yeast in response to unique triplet (nonsense) and quadruplet (frameshift) codons. ${ }^{7-12}$ Here we use this methodology to genetically encode $\mathrm{pNO}_{2}$-Phe in bacteria with high fidelity and efficiency. In addition, we illustrate the use of the $\mathrm{pNO}_{2}-\mathrm{Phe} /$ Trp pair as a distance probe in a coiled-coil protein.

$\mathrm{pNO}_{2}$-Phe was incorporated into proteins in Escherichia coli by means of a unique amber suppressor tRNA (mutRNA ${ }_{\mathrm{CUA}}^{\mathrm{Tyr}}$ )/ aminoacyl tRNA synthetase (MjTyrRS) pair derived from a Methanococcus jannaschii tRNA $^{\text {Tyr}} /$ TyrRS pair. The specificity of MjTyrRS was altered so that the synthetase specifically charges mutRNA ${ }_{\mathrm{CUA}}^{\mathrm{Tyr}}$ with $\mathrm{pNO}_{2}$-Phe and no endogenous amino acid. A MjTyrRS library was constructed based on the crystal structure of a mutant MjTyrRS that selectively charges mutRNA ${ }_{\mathrm{CUA}}^{\mathrm{Tyr}}$ with $p$-bromophenylalanine. ${ }^{13}$ The $\mathrm{Ser}^{107}$, Pro ${ }^{158}$, $\mathrm{Leu}^{159}$, and $\mathrm{Glu}^{162}$ active site mutations were preserved in this library, and random mutations were introduced at $\mathrm{Leu}^{32}$, $\mathrm{Leu}^{65}$, $\mathrm{His}^{70}, \mathrm{Gln}^{109}$, $\mathrm{His}^{160}$, and $\mathrm{Tyr}^{161}$. To identify a synthetase specific for $\mathrm{pNO}_{2}$-Phe, alternating rounds of positive selection (based on suppression of an amber stop codon in the chloramphenicol acetyltransferase (CAT) gene in the presence of $1 \mathrm{mM}$ unnatural amino acid) and negative selection (based on suppression of amber nonsense mutations in the toxic barnase gene $)^{14}$ were carried out. After several rounds of positive and negative selection, a clone was evolved whose survival at high concentration of chloroamphenicol $(120 \mu \mathrm{g} / \mathrm{mL})$ was dependent on the presence of $\mathrm{pNO}_{2}$-Phe. These results suggest that the evolved synthetase has higher specificity for $\mathrm{pNO}_{2}$-Phe than for endogenous amino acids. Sequencing revealed the following mutations in this evolved synthetase compared to the wild-type MjTyrRS: Tyr $^{32} \rightarrow$ Leu, $\mathrm{Glu}^{107} \rightarrow$ Ser, Asp ${ }^{158} \rightarrow$ Pro, $\mathrm{Ile}^{159} \rightarrow$ Leu, His ${ }^{160} \rightarrow$ Asn, and Leu ${ }^{162} \rightarrow$ Glu.

To test the ability of the evolved synthetase (mutNO ${ }_{2}-\mathrm{PheRS}$ ) and mutRNA $\mathrm{CUA}_{\mathrm{CU}}^{\mathrm{Tyr}}$ to selectively incorporate $\mathrm{pNO}_{2}$-Phe into proteins, an amber stop codon was substituted at a permissive site $\left(\mathrm{Lys}^{7}\right)$ in the gene for the $\mathrm{Z}$ domain protein with a C-terminal hexameric His tag. ${ }^{15}$ Cells transformed with mutNO ${ }_{2}-\mathrm{PheRS}$, mutRNA $_{\mathrm{CUA}}^{\mathrm{Tyr}}$ and the mutant $\mathrm{Z}$ domain gene were grown in the presence of $1 \mathrm{mM} \mathrm{pNO}_{2}$-Phe in minimal medium containing $1 \%$ glycerol and $0.3 \mathrm{mM}$ leucine (GMML medium). The mutant protein was purified by $\mathrm{Ni}^{2+}$ affinity column and subsequently analyzed by SDS-PAGE and MALDI-TOF (Figure 1). The yield of mutant $\mathrm{Z}$-domain protein is $2 \mathrm{mg} / \mathrm{L}$ in the presence of $\mathrm{pNO}_{2}-\mathrm{Phe}$, but is insignificant in the absence of $\mathrm{pNO}_{2}$-Phe (Figure 1a), indicating a
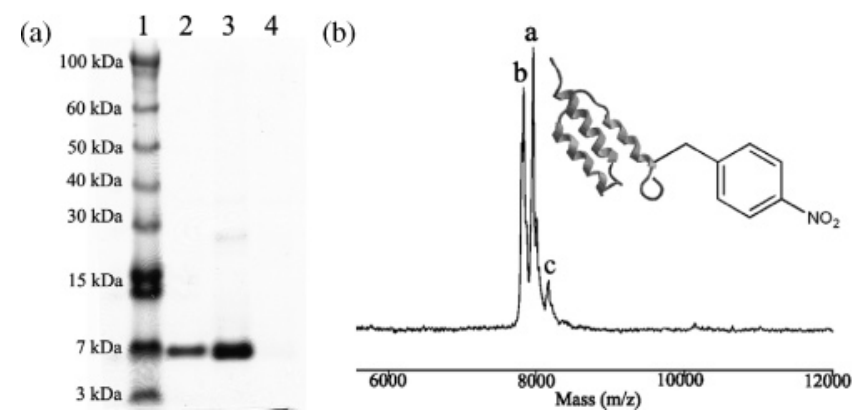

Figure 1. (a) SDS-PAGE analysis of Lys $\rightarrow$ TAG Z-domain protein expressed under different conditions. Lane 1: molecular mass marker; lane 2: expression with WT MjTyrRS; lane 3: expression with mutNO $\mathrm{N}_{2}-\mathrm{PheRS}$ in the presence of $\mathrm{pNO}_{2}$-Phe; lane 4: expression with mutNO $\mathrm{N}_{2}-\mathrm{PheRS}$ in the absence of $\mathrm{pNO}_{2}$-Phe. The SDS-PAGE gel was stained with GelCode Blue stain reagent. (b) MALDI-TOF analysis of $\mathrm{pNO}_{2}$-Phe incorporated Z-domain protein: peak a can be assigned to the full length mutant $\mathrm{Z}$ domain, peak $\mathrm{b}$ is assigned to the $\mathrm{Z}$ domain protein without the first Met, peak $\mathrm{c}$ is the matrix adduct.

very high fidelity for the incorporation of the unnatural amino acid. Moreover, the MALDI-TOF spectrum shows two peaks at $\mathrm{m} / \mathrm{z}=$ 7958 and 7828 (Figure 1b), which match the expected molecular weight for the $\mathrm{pNO}_{2}$-Phe Z-domain mutant $(\mathrm{m} / \mathrm{z}=7958)$ and the molecular weight for this mutant protein with the loss of its first methionine $(\mathrm{m} / \mathrm{z}=7826){ }^{16}$

Next, we examined the utility of $\mathrm{pNO}_{2}$-Phe as a distance probe through its ability to quench the intrinsic fluorescence of tryptophan residues in proteins. This $\mathrm{Trp} / \mathrm{pNO}_{2}-\mathrm{Phe}$ fluorophore-quencher pair was incorporated into a model GCN4 leucine zipper protein, which forms a parallel coiled-coil homodimer. ${ }^{17,18}$ The DNA binding region of the GCN4 gene (676-840 bp, bZIP), which does not encode any tryptophans, was cloned from the yeast genome into the protein expression vector $\mathrm{pET}-26 \mathrm{~b}$ with an additional N-terminal Met and a C-terminus $\mathrm{Leu}^{57} \mathrm{Glu}^{58}$ (encoding a Xho I restriction site) followed by a 6XHis tag (Scheme 1a). Site-directed muta-

Scheme 1

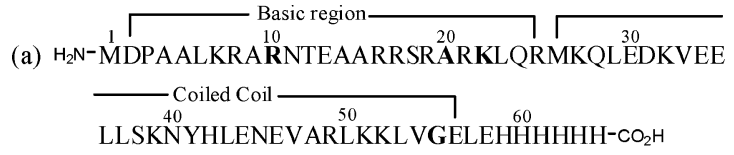

\section{(b) 5'-TTCCTATGACTCATCCAGTT} AGGATACTGAGTAGGTCAAA-5

(a) Sequence of the model GCN4 bZIP protein; mutation sites are indicated in bold. (b) 20-mer bZIP duplex DNA binding site.

genesis was then used to substitute amino acids at selected sites with either Trp or $\mathrm{pNO}_{2}$-Phe (TAG codon). The bZIP expression vector as well as a plasmid containing both mutNO ${ }_{2}$-PheRS and mutRNA $\mathrm{CUA}_{\mathrm{CU}}^{\mathrm{Ty}}$ were cotransformed into E. coli BL21(DE3) cells, 
(a)

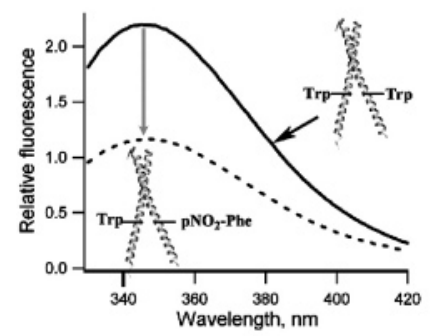

(b)

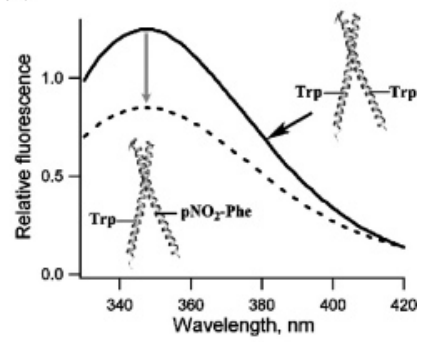

(c)

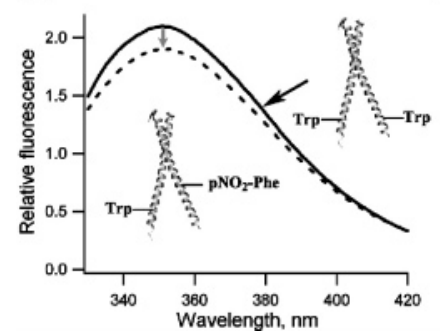

(d)

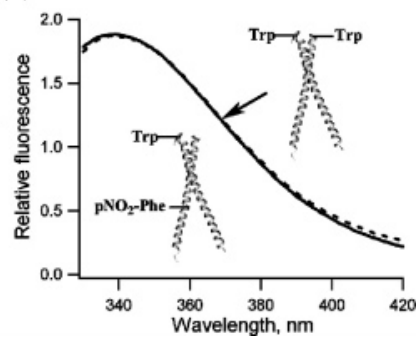

Figure 2. Steady-state fluorescence spectra of tryptophan containing bZIP proteins with the $\operatorname{Trp}$ mutation introduced at residue (a) $\operatorname{Trp}^{22}$, (b) $\operatorname{Trp}^{20}$, (c) $\operatorname{Trp}^{10}$ and (d) $\operatorname{Trp}^{55}$. The spectra were recorded with $20 \mu \mathrm{M}$ of bZIP duplex DNA binding site in the absence (solid lines) and the presence (broken lines) of $10 \mu \mathrm{M} \mathrm{pNO}_{2}-\mathrm{Phe}^{22}$ bZIP mutant.

which were then grown in the presence of $1 \mathrm{mM} \mathrm{pNO}_{2}$-Phe in GMML minimal media. The 64 residue mutant bZIP proteins were purified by $\mathrm{Ni}^{2+}$ affinity column and characterized by SDS-PAGE and MALDI-TOF analyses (see Supporting Information).

The coiled-coil region of bZIP consists of residues 26-56 with the leucine heptad repeat at positions 29, 36, 43, and 50. A Trp was substituted for $\mathrm{Lys}^{22}$ at a surface accessible site in the noninteracting region of the coiled-coil; a Lys ${ }^{22}$ to $\mathrm{pNO}_{2}$-Phe mutant was also generated at this position. The fluorescence spectrum of the $\operatorname{Trp}^{22}$ bZIP mutant $(10 \mu \mathrm{M})$ was measured at $22{ }^{\circ} \mathrm{C}$ with 295 $\mathrm{nm}$ excitation in $50 \mathrm{mM}$ phosphate-buffered $300 \mathrm{mM}$ saline solution ( $\mathrm{pH}$ 8.0) with $20 \mu \mathrm{M}$ of the bZIP DNA recognition site (Scheme $1 b)^{19}$ in both the absence and presence of stoichiometric amounts of the $\mathrm{pNO}_{2}-\mathrm{Phe}^{22}$ mutant (Figure 2a). The observed fluorescence intensity of the $\operatorname{Trp}^{22}$ mutant was reduced by $47 \%$ in the presence of stoichiometric $\mathrm{pNO}_{2}-\mathrm{Phe}^{22}$ mutant protein. Because the substitutions are made in a noninteracting region of the protein, there should be a statistical mixture of a 2:1:1 ratio of $\mathrm{Trp}^{22} / \mathrm{pNO}_{2}-\mathrm{Phe}^{22}, \mathrm{pNO}_{2}$ $\mathrm{Phe}^{22} / \mathrm{pNO}_{2}-\mathrm{Phe}^{22}$, and $\operatorname{Trp}^{22} / \operatorname{Trp}^{22}$ bZIP dimers. On the basis of the reported $K_{\mathrm{d}}$ of $0.5 \mu \mathrm{M}$ for the coiled-coil homodimer, ${ }^{20}$ the maximum fluorescence quenching efficiency can be estimated to be $\sim 45 \%$, which is very close to that observed for the $\operatorname{Trp} 22 / \mathrm{pNO}_{2}-$ $\mathrm{Phe}^{22}$ pair. This result indicates that the $\mathrm{pNO}_{2}-\mathrm{Phe}$ group is indeed an efficient quencher of tryptophan fluorescence. Similar results were obtained when quenching experiments were carried out under the same conditions in the absence of the duplex DNA.

To further investigate the distance-dependence of the fluorescencequenching interaction, $\operatorname{Trp}^{10}, \operatorname{Trp}^{20}$, and $\operatorname{Tr} \mathrm{P}^{55}$ mutant proteins were also generated, and their fluorescence spectra were again measured in the absence and presence of stoichiometric amounts of the $\mathrm{pNO}_{2}$ Phe $^{22}$ mutant (Figure 2, curves $\mathrm{b}-\mathrm{d}$ ). The distance separations between Trp and $\mathrm{pNO}_{2}$-Phe in the $\mathrm{Trp} / \mathrm{pNO}_{2} \mathrm{Phe}$ dimeric proteins were estimated to be $6,15,26$, and $49 \AA$ for the $\operatorname{Trp}^{22}, \operatorname{Trp}^{20}, \operatorname{Trp}^{10}$, and $\operatorname{Trp}^{55}$ mutants, respectively, based on the crystal structure of the wild-type bZIP dimer. ${ }^{19}$ Due to the larger spatial separation between Trp and $\mathrm{pNO}_{2}$-Phe, the presence of $\mathrm{pNO}_{2}-\mathrm{Phe}^{22} \mathrm{bZIP}$ results in a smaller quenching efficiency $(32 \%)$ for the $\operatorname{Trp}^{20}$ mutant compared to that for the $\operatorname{Trp}^{22}$ mutant. The $\mathrm{pNO}_{2}-\mathrm{Phe}^{22} \mathrm{bZIP}$ mutant has minimal effect on the fluorescence quantum yield of either the Trp ${ }^{10}$ mutant or the $\operatorname{Trp}^{55}$ mutant. This result clearly shows that the strength of the fluorophor-quencher interaction between Trp and $\mathrm{pNO}_{2}$-Phe is related to the distance between these two moieties.

In conclusion, we have evolved a mutant MjTyrRS synthetase to genetically encode $p$-nitrophenylalanine $\left(\mathrm{pNO}_{2}-\mathrm{Phe}\right)$ in $E$. coli with high fidelity and efficiency. The applicability of $\mathrm{pNO}_{2}-\mathrm{Phe}$ as a biophysical probe was demonstrated using a model GCN4 bZIP leucine zipper protein, in which $\mathrm{pNO}_{2}$-Phe quenched the fluorescence of Trp in a distance dependent fashion. Thus, the site-specific incorporation of $\mathrm{pNO}_{2}$-Phe into proteins should be a useful tool to study protein folding and conformational changes as well as protein-protein interactions. In addition, we are currently exploring the utility of the $\mathrm{pNO}_{2}$-Phe moiety for the production of immunogenic proteins for vaccine production.

Acknowledgment. This work was supported by the Department of Energy (Grant No. ER46051).

Supporting Information Available: Experimental details. This material is available free of charge via the Internet at http://pubs.acs.org.

\section{References}

(1) Dong, M.; Hadac, E. M.; Pinon, D. I.; Miller, L. J. Mol. Pharmacol. 2005 67, 1892-1900

(2) Wang, W.; Liang, T. C. Biochem. Biophys. Res. Commun. 1994, 201, $835-840$.

(3) Murakami, H.; Hohsaka, T.; Ashizuka, Y.; Sisido, M. J. Am. Chem. Soc. 1998, 120, 7520-7529.

(4) Taki, M.; Hohsaka, T.; Murakami, H.; Taira, K.; Sisido, M. J. Am. Chem. Soc. 2002, 124, 14586-14590.

(5) Noren, C. J.; Anthony-Cahill, S. J.; Griffith, M. C.; Schultz, P. G. Science 1989, 244, 182-188.

(6) Hohsaka, T.; Ashizuka, Y.; Murakami, H.; Sisido, M. Nucleic Acids Res. 2001, 29, 3646-3651.

(7) Wang, L.; Brock, A.; Herberich, B.; Schultz, P. G. Science 2001, 292, 498-500.

(8) Chin, J. W.; Cropp, T. A.; Anderson, J. C.; Mukherji, M.; Zhang, Z. W.; Schultz, P. G. Science 2003, 301, 964-967.

(9) Zhang, Z.; Alfonta, L.; Tian, F.; Bursulaya, B.; Uryu, S.; King, D. S.; Schultz, P. G. Proc. Natl. Acad. Sci. U.S.A. 2004, 101, 8882-8887.

(10) Anderson, J. C.; Wu, N.; Santoro, S. W.; Lakshman, V.; King, D. S. Schultz, P. G. Proc. Natl. Acad. Sci. U.S.A 2004, 101, 7566-7571.

(11) Wang, L.; Schultz, P. G. Angew. Chem., Int. Ed. 2005, 44, 34-66.

(12) Tian, F.; Tsao, M.-L.; Schultz, P. G. J. Am. Chem. Soc. 2004, 126, $15962-$ 15963.

(13) Turner, J. M.; Graziano, J.; Spraggon, G.; Schultz, P. G. Proc. Natl. Acad Sci. U.S.A. 2006, in press.

(14) Xie, J.; Schultz, P. G. Methods 2005, 36, 227-238.

(15) Wang, L.; Zhang, Z.; Brock, A.; Schultz, P. G. Proc. Natl. Acad. Sci. U.S.A. 2003, 100, 56-61.

(16) Tsao, M.-L.; Tian, F.; Schultz, P. G. ChemBioChem 2005, 6, 2147-2149

(17) O'Shea, E. K.; Rutkowski, R.; Kim, P. S. Science 1989, 243, 538-542.

(18) O'Shea, E. K.; Klemm, J. D.; Kim, P. S.; Alber, T. Science 1991, 254, 539-544.

(19) Ellenberger, T. E.; Brandl, C. J.; Struhl, K.; Harrison, S. C. Cell 1992 $71,1223-1237$.

(20) Wendt, H.; Baici, A.; Bosshard, H. R. J. Am. Chem. Soc. 1994, 116 , 6973-6974.

JA058262U 